Research, part of a Special Feature on Public policies and management of rural forests: lasting alliance or fool's dialogue?

\title{
Logging Concessions and Local Livelihoods in Cameroon: from Indifference to Alliance?
}

\author{
Guillaume Lescuyer $^{1,2}{ }^{\text {Samuel Assembe Mvondo }}{ }^{2}$ Julienne Nadège Essoungou $^{2}{ }^{\text {,Vincent Toison }}{ }^{3}$, \\ Jean-François Trébuchon ${ }^{1}$, and Nicolas Fauvet ${ }^{1}$
}

\begin{abstract}
Sustainable forest management gives the opportunity to better integrate the way local populations use their customary "village terroirs" in the logging activities. This requirement is explicitly stated in all forest laws of the Congo Basin countries but its implementation on the field remains under documented. In Cameroon, 30 forest management plans (FMP) for logging concessions have been reviewed to assess how they effectively include customary use rights. The integration of use rights into the FMPs is heterogeneous but always with very low enforcement. The weak influence of the FMP application on local practices is confirmed with an empirical survey that shows that natural, financial, and physical capitals in two villages of the eastern region of Cameroon have been little affected by the adjoining logging concession over the latest 13 years. Extrasector policies such as agriculture, road infrastructure, techniques, and land tenure are the real drivers of socioeconomic change at the local scale. Their impacts are facilitated by the presence of the logging concessions, which can contribute indirectly to improve local livelihoods.
\end{abstract}

Key Words: Central Africa; customary rights; socioeconomic impacts; sustainable forest management

\section{INTRODUCTION}

The forest zone of Central Africa is characterized by low population density that may give the impression that many areas are uninhabited and devoid of customary rights (de Wasseige et al. 2009). In fact, many participatory mapping experiences show it is rare to find forest areas that do not undergo a form of ownership by human populations (Diaw and Oyono 1998, Lescuyer and Emerit 2005). These forms of ownership and tenure are varied. They are the product of different types of customary rights generally distinguishing access, withdrawal, management, use, and alienation (Schlager and Ostrom 1992, Le Roy et al. 1996). They are exercised by various actors, ranging from the largest group to the single individual (Diaw 1997, Lescuyer 2006) on several types of resources such as land, game, trees, and nontimber forest products (NTFP). Thus, customary modes of land and forest tenures are characterized by a mix of more or less explicit rules; which application is used depends on the actors and resources involved.

Traditional rights are applied in an area that local people regard as theirs by custom. It is often referred to as "village terroir" (Le Roy et al. 1996, Karsenty et al. 1997, Vermeulen and Karsenty 2001). Apart from residential areas, village terroirs are composed of a mosaic of areas more or less humanized, where crop zones are intertwined with forest ecosystems (Carrière 2002, Robiglio 2008). In rural areas, livelihoods are strongly dependent on the resources localized within the village terroirs. Customary rights associated with these village terroirs are recognized by the national laws of the Congo Basin countries, but without formalizing the existence of these terroirs. In the absence of any regulatory provision, forest areas of Cameroon are used according to customary rights, the latter being defined and implemented according to the understanding of communities, insofar as they follow the principles of the national laws.

However the state remains the legal manager of the forest area on which it has delineated a private domain of the state that covers $30 \%$ of the country's land. Several assignments can be attributed to this private domain, but logging is largely dominant. It is through a logging concession that the state gives a company the exclusive right to exploit timber resources in its private domain for a specified period. In return, concessionaires must meet several requirements in terms of taxation or provision of public goods. The agreement between the state and the concessionaire takes the form of a convention for exploitation, which is accompanied by a forest management plan (FMP) and specifications. These two documents must ensure the ecological, economic, and socially sustainable management of the forest.

In Central Africa, any logging concession covers a large area, about 75,000 ha on average in Cameroon, and necessarily overlaps with other land uses, including village terroirs. This forest management model emphasizes the industrial exploitation of timber resources, other ecosystem's goods and services being considered as secondary (Panayotou and Ashton 1992, Hanley et al. 1994). Moreover, being primarily an agreement between the state and a private operator, the logging concession is usually criticized for neglecting the interests of other stakeholders such as the local population whose uses predate the existence of the state and the presence of logging companies (Mayers and Bass 2004, Alden Wily 2011). The combination of the industrial exploitation of timber 
species often by foreign companies and the customary uses of forest resources by local people is debated in Central Africa. For some, the logging concession model remains relevant but needs to be reformed to better integrate all forest goods and services as well as the aspirations of local stakeholders (Nasi et al. 2006, Singer and Karsenty 2008). The political choice of sustainable forest management in the 1990s and the implementation of private certification schemes support this evolution (Delvingt and Lescuyer 2007, Topa et al. 2009, Cerutti et al. 2011).

Another current of thought questions the model of timber concession based on a FMP; besides being seen as a legacy of the colonial period, the concession exhibits significant failings such as the despoilment of human populations (Hoare 2007, Long 2007, Alden Wily 2011), a low impact on rural poverty (Counsell 2007, van Dorp 2007), the delegitimation of local authorities (Molnar et al. 2010), and the maintenance of poor governance in the forestry sector (Counsell 2007, Wilson 2007).

The debate between proponents of both positions almost always focuses on the first steps of the forest management process, with concerns over the delimitation of concessions, their mode of attribution, or the content of the FMPs. However, there is little information on the implementation of the FMPs and their actual impacts on village terroirs and local livelihoods. To examine the connection between the application of the concession model and the variation of local livelihoods, the article focuses on the Cameroon situation, the most advanced country in enforcing forest management in the Congo Basin region (de Wasseige et al. 2009), and considers two levels of analysis. After presenting the methods and context of study, we assess the overall impact at the national scale of direct contributions from logging concessions to their surrounding villages. We then consider how local livelihoods in two communities have evolved during the last decade in the vicinity of a logging concession. We conclude on the potentiality of the forest concession model to indirectly favor local livelihoods.

\section{METHODS}

Three survey methods were implemented: review of FMPs, interviews with managers of forest concessions, and monitoring of local practices and infrastructure. The integration of customary rights in the FMPs is analyzed on the basis of 30 FMPs approved by the Ministry of Forests (Fig. 1). They were selected on the basis of their availability at the Ministry of Forests or at international cooperation agencies.

In May 2011, Cameroon had 114 logging concessions, of which 74 had a FMP approved by the forestry administration. The reviewed FMPs regard concessions that are located throughout the forest area. They were examined by using the same analytical framework including variables such as authorized activities in the various specialized areas and existence of conflict resolution structures.
Fig. 1. Sample of logging concessions under review.

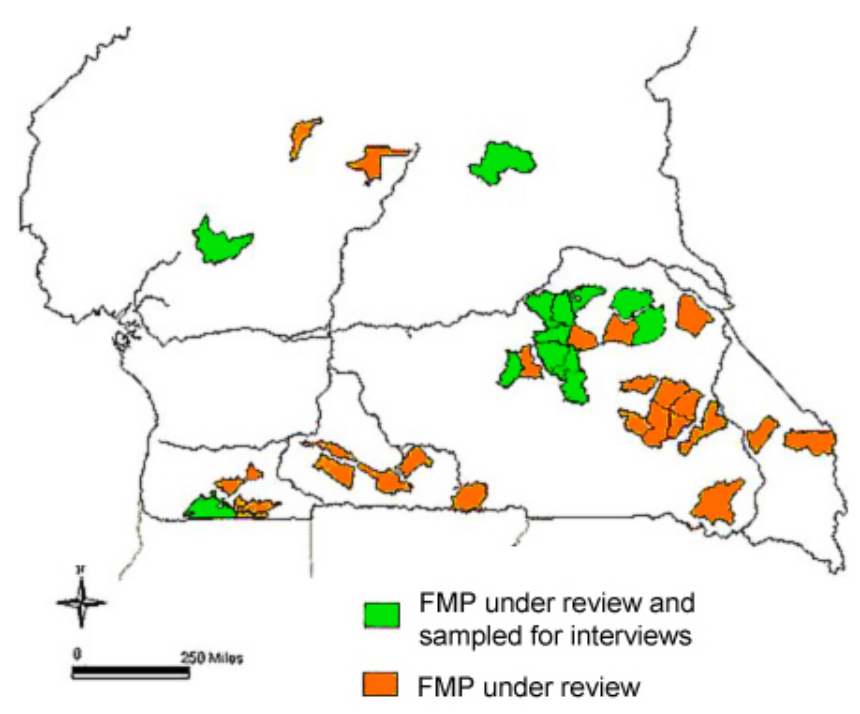

After the review of 30 FMPs, nine enterprises were contacted to make them explain how they concretely enforce the regulation of customary rights enacted in their FMP. Willingness to collaborate on this survey was the main criterion for selecting these companies. Individual, semiopen interviews were conducted in each company with the person in charge of the implementation of the FMP.

Last, the analysis of the actual impact of the logging concession model on customary rights and local livelihoods is based on a case study. This concession is located in the eastern region of Cameroon and covers an area of 73,600 ha. It has been officially operated by a European company since 2002, according to a FMP approved in 2005. This company has been providing massive efforts in recent years to obtain a certificate of sustainable management, but as of the present it can only prove that the timber extracted from its concession abides by the national regulations. This concession is located approximately $150 \mathrm{~km}$ from the regional capital, in a relatively landlocked area. It is surrounded by 42 villages with approximately 11,200 people. Its economic, technological, demographic, social, and ecological backgrounds are shared by the vast majority of concessions located in the regions of eastern and southern Cameroon (Ruiz-Pérez et al. 2005).

Two villages, Gouté and Djémiong, were selected for the assessment of the concession's impacts on local livelihoods. They are representative of rural isolated areas in Cameroon (Lescuyer 2000, Takforyan 2001). They are medium in size, with 121 residents in Gouté and 397 in Djémiong. Their economies are characterized by a strong dependence on agricultural and forest resources. These populations remain below the poverty-line level, with an average individual income around $235 € /$ year. The two villages are located in the 
vicinity of a logging concession but are not close to the city where the industrial sawmill is based; therefore, even if local forest practices are indeed modified by the timber harvesting operations that have occurred over the last five years near the villages, the two villages' economies are under little influence of the presence of hundreds of workers employed by the logging company.

The impact of this concession is estimated from the variation of local uses of forest resources and space, the number and quality of collective infrastructure, and the income level in the two villages between 1995 and 2008. This small sample is because of two methodological choices: (1) a direct monitor of local practices rather than interviews with villagers on their forest and farm practices; (2) a comparison of the current practices with the same practices in 1995, before establishment of the concession, to propose a diachronic analysis. Availability of previous information and cumbersome investigations prevent extending these surveys to a wider area.

In both villages, a large sample of households was followed with the same survey protocols for both periods. In 1995, all households were followed in the two villages, i.e., 20 households in the village of Gouté and 30 households for Djémiong. These same households were selected in 2008, but the 20 households in Goute then represented $87 \%$ of the total number, and the 30 households in Djémiong was a sample of $73 \%$ of the total number of households in this village. Each household was surveyed every week for a full year. A first questionnaire focused on money inflows and outflows in budget(s) of the household during the previous week. A second questionnaire recorded all forest resources extracted during the previous week by all household members. These questionnaires were filled in with the head of the household together with the other household's members.

The evolution of hunting activities and the change in the households' revenues were assessed with statistical nonparametrical tests. They were performed with SPSS 16.0 with a significant level of $95 \%$. The evolution of agricultural areas within the logging concession was described on the basis of a series of three satellite pictures, the first in 1984 (dry season, Landsat TM), the second in 1999 (dry season, Landsat ETM +), and third in 2007 (short rainy season, Aster image). The images were photo-interpreted on the basis of spectral signatures, according to a simplified classification highlighting areas of dense forest and agricultural areas over a distance of $1 \mathrm{~km}$ on either side of the roads and tracks.

\section{DIRECT IMPACTS OF FOREST CONCESSIONS ON LOCAL LIVELIHOODS: A MACROLEVEL ANALYSIS}

The beginning of forest exploitation and granting of concessions are related to the early decades of colonization in the Central Africa countries (Coquery-Vidrovitch 2001). This was primarily a silvicultural approach that survived until mid-1980 (Valeix 1999, Nasi et al. 2006). An integrated forest management model emerged from the Rio de Janeiro Earth Summit in 1992 and through the development of the Tropical Forestry Action Plans (Cailliez 1991, Nguinguiri 1999). In Cameroon, the participatory forest management became the norm with the advent of the forestry legislation of 1994. Since then, besides the involvement of local stakeholders in this process, forest management must also contribute formally and directly to local socioeconomic development. In particular, logging concession holders must face three requirements: commitment of local stakeholders in forest management, contribution to infrastructure, and regulation of customary use rights. Each of these is considered, through literature review for the first two and on the basis of the 30 FMPs reviews and concessionaires' interviews for the latter.

\section{Involvement of local population in the forest management process}

Logging companies must involve local people at various stages of the forest management process, i.e., the delineation of the concession, the preliminary socioeconomic survey, the creation of a conflict resolution structure, and the establishment of village organizations in charge of monitoring the socioeconomic achievements of the company (Collas de Chatelperron 2005). As a consequence, many village committees are put in place but face three important obstacles : (1) they are often short-lived and do not allow communities to organize themselves over the medium or long term (Oyono 2004, Lescuyer 2006); (2) they are frequently the subject of misappropriation by elites villagers, who turn them into a tool for economic or political power (Karsenty 1999, Mbairamadji 2009); (3) they remain highly dependent, both in financial and technical terms, on the logging company or other supportive external actors (Assembe Mvondo 2006, Oyono et al. 2006). As a result, without being artificial, the process of local participation in forest management is still largely dominated by the logging company and moderately integrates the concerns of surrounding communities.

\section{Contributions to infrastructure}

Logging companies have to participate in improving the living conditions of local populations. This contribution takes two forms. The first requirement is the payment to the communities of an amount equivalent to $10 \%$ of the annual forestry fee. This mechanism has been met with limited success (Oyono 2005, Assembe Mvondo 2006, Lescuyer et al. 2008, Morrison et al. 2009). The second obligation for the logging company is the provision of "social works" to communities, as indicated in the specifications that go with the FMP. Here again, the impact at the village level is weak for two reasons: (1) contributions to social works are generally recommended but not mandatory for the concessionaire; (2) specifications generally remain confidential and these documents are hardly accessible to rural populations (Bigombe Logo 2004, Lescuyer 2007). 
Table 1. Legal constraints to local uses in a logging concession.

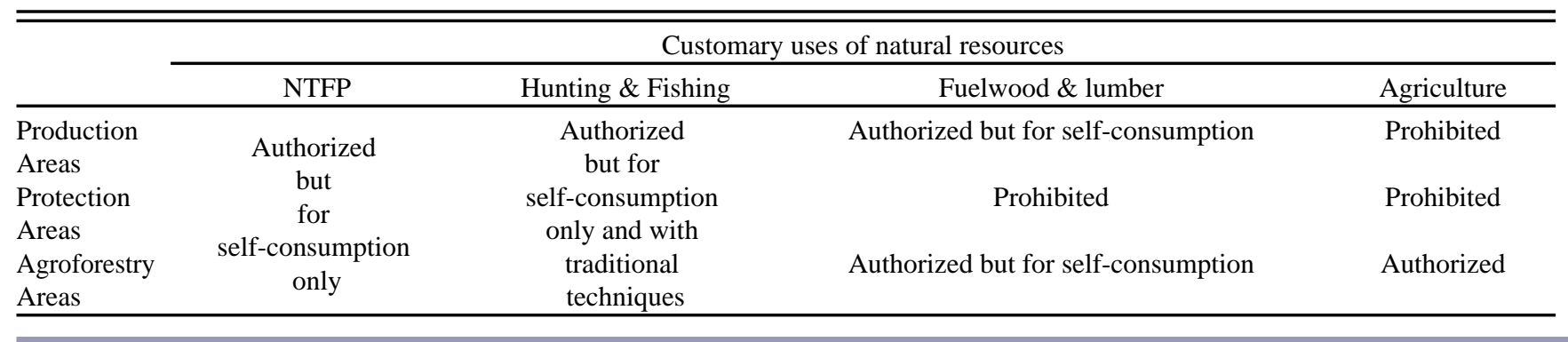

\section{Regulation of customary use rights}

In addition to its formal obligations, the logging company must also indicate in its FMP how customary use rights will be taken into account and administered within the concession. Inside the concession, microzoning sorts the areas that are assigned to timber logging (production area), those turned to the protection of ecosystems (protection area) and, sometimes, those used for agroforestry (agroforestry area). Four local uses, i.e., NTFP extraction, hunting, fuelwood and lumber, and agriculture, are usually considered in the FMP and regulated according to the forestry law (Table 1).

The exercise of use rights in these various areas is detailed in the FMP. However their concrete influence on local practices remains poorly documented in Central Africa (Karsenty et al. 2008). Figure 2 to Figure 5 summarize how these four practices are regulated within the 30 reviewed FMPs. There are three possibilities: either the use is authorized, or it is prohibited, or is not mentioned. In these figures, the bordered blocks correspond to the requirements of the law.

Fig. 2. Regulation of agriculture in 30 forest management plans.

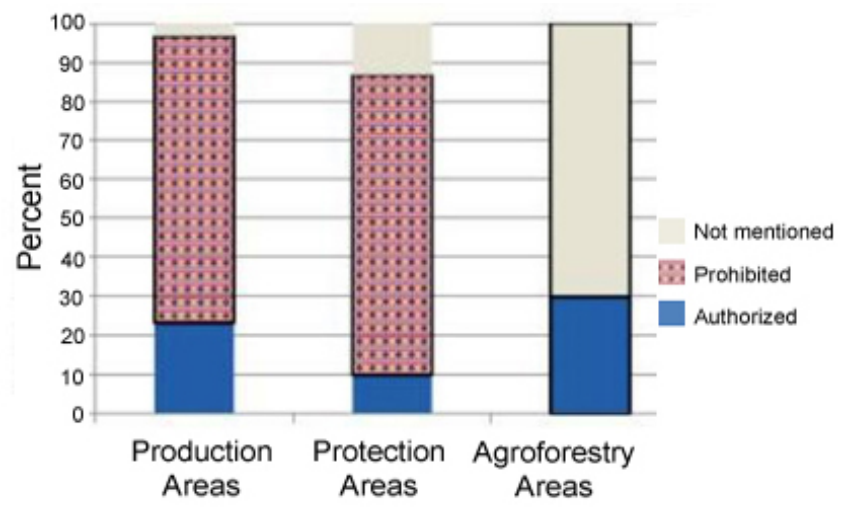

Agroforestry areas are established in one third of the FMPs although agriculture is in principle prohibited within the logging concessions. Two reasons explain this irregularity.
First, the concession has been defined and announced as proposed by the national zoning plan, which did not properly take into account some agricultural areas, and obviously without the participation of residents. Once the concession was announced, the logging company created an agroforestry area within its concession but without allowing its extension. Second, if the law precludes such a use in logging concessions, the official software to elaborate FMPs allows this possibility. Forest managers have therefore used this option, which was then validated by the forestry administration.

Fig. 3. Regulation of hunting in 30 forest management plans.

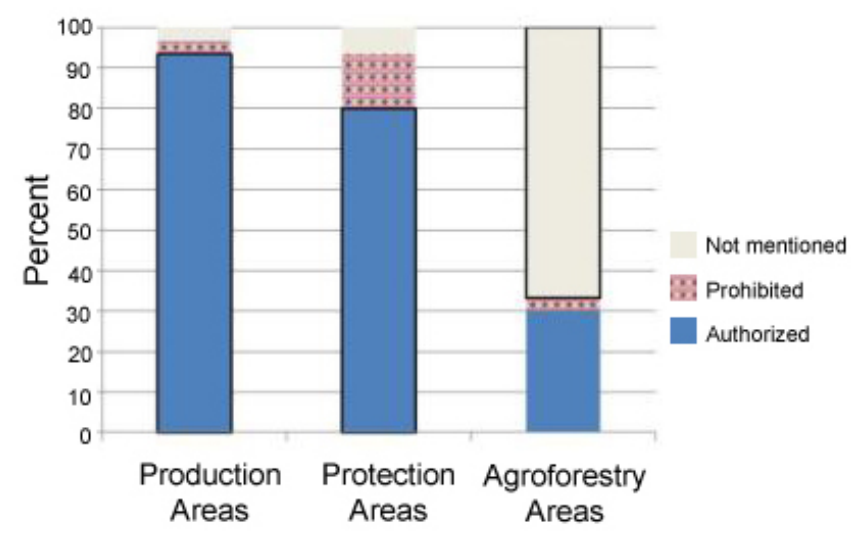

In the production areas, the regulation of local uses is consistent with regulatory requirements; over $83 \%$ of the consulted FMPs permit hunting, fishing, collection of NTFPs, and timber harvesting, provided that these products are intended for self-consumption. Consistency with forestry regulations is lower for the conservation areas; between 70 and $83 \%$ of FMPs regulate customary rights in accordance with the provisions of forestry law.

The description of the use rights regulated in the FMPs does not necessarily mean that these measures are implemented on the ground. Nine forest managers expressed their opinion on the effectiveness of the restrictions imposed on customary 
rights in their concessions. Figure 6 shows the degree of implementation of these requirements in these concessions.

Fig. 4. Regulation of nontimber forest products gathering in 30 forest management plans.

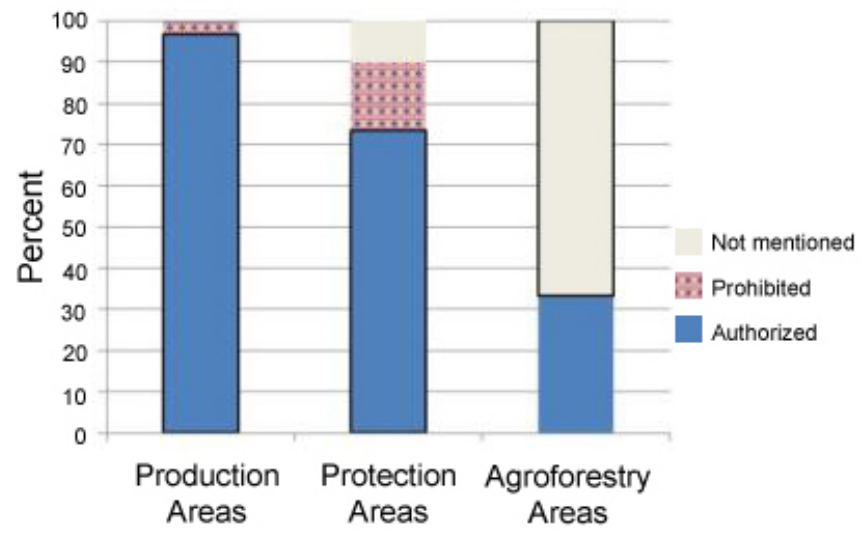

Fig. 5. Regulation of fuelwood and timber extraction in 30 forest management plans.

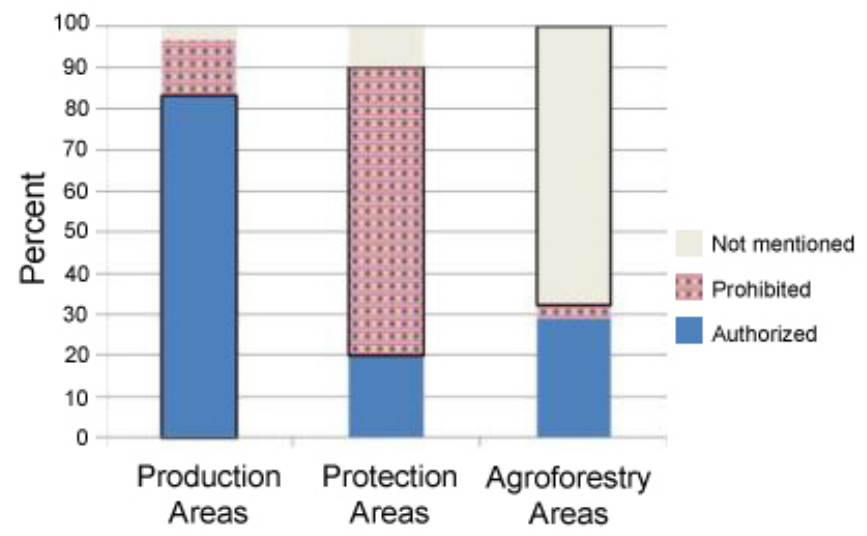

Agriculture is the easiest use to control and regulate by the logging companies because it is a sedentary and easily detectable practice. By contrast, it is much more difficult for companies to fight against the removal of game, NTFP, and wood. Two reasons explain this failure: (1) it is very difficult to know whether the products are actually taken for selfconsumption, as required by law, (2) they are fleeting and mobile uses exercised by a large number of people.

The analysis of the implementation of restrictions on customary use rights in forest concessions in Cameroon reveals the meager success of companies in enforcing their own regulations. Except for agricultural practices and for some occasional military operations against poaching or illegal timber harvesting camps, there is an overall tolerance by companies of the withdrawals in the forest by local people (Vandenhaute and Doucet 2006). This weak enforcement puts in perspective the discourse on the despoilment of customary rights where a concession is granted. In theory, the forestry law and the FMP restrict these rights by prohibiting farming and allowing only extractions for self-consumption in forest concessions. In practice, these restrictions are little applied because they are too expensive and of little use to the company.

Fig. 6. Enforcement of local uses restrictions in nine concessions.

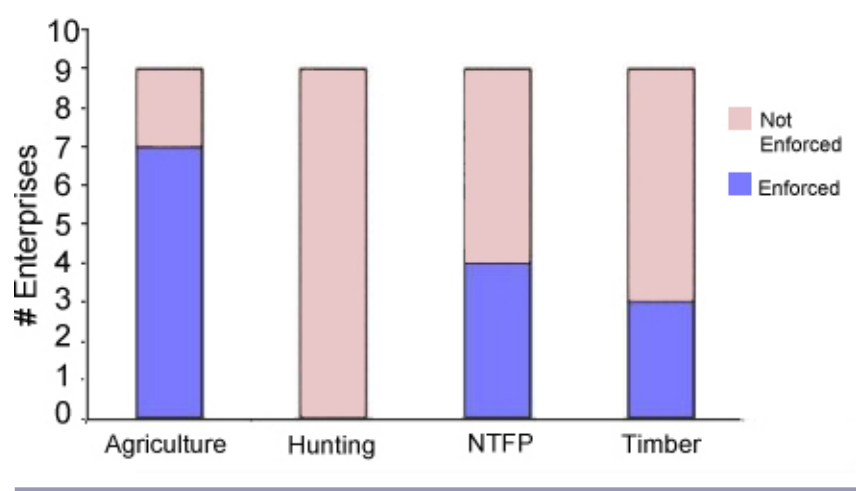

The review of available data at the macrolevel shows that the relationship between logging concession and village terroirs is close to neutrality. Forest management does not directly contribute to local economic development but does not either constrain the ways people use forest resources for their living.

\section{DIRECT AND INDIRECT IMPACTS OF FOREST CONCESSIONS ON LOCAL LIVELIHOODS: A MICROLEVEL ANALYSIS}

If forest management has not had a substantial direct impact on local livelihoods, it can however exercise some indirect influence on their evolution. The direct and indirect influence is assessed on the basis of a case study that recapitulates livelihood change in two villages of eastern Cameroon between 1995 and 2008, while their customary forests were included in a logging concession in 2002.

Following the sustainable livelihoods framework (Chambers and Conway 1992, Scoones 1998), local livelihood is composed of a portfolio of natural, manufactured, financial, human, and social capitals. In the case study, three sets of variables were selected to embody local livelihoods: (1) the quantity of collective or semicollective installations that stands for manufactured capital; (2) the intensity and spatial scope of two activities related to natural resources, i.e., hunting and shifting cultivation in the concession, that constitute a proxy for natural capital; and (3) the households' income levels that represent financial capital. Human and social capitals have little evolved over the period under study. 
Table 2. Evolution of the physical capital in the two sampled villages.

\begin{tabular}{|c|c|c|c|c|c|c|}
\hline \multirow{2}{*}{$\begin{array}{l}\text { Asset of physical } \\
\text { capital }\end{array}$} & \multirow[t]{2}{*}{ Indicator } & \multicolumn{2}{|c|}{ Gouté } & \multicolumn{2}{|c|}{ Djémiong } & \multirow[t]{2}{*}{ Contributors } \\
\hline & & 1995 & 2008 & 1995 & 2008 & \\
\hline state of the road & according to villagers' perceptions & poor & average & average & average & $\begin{array}{l}\text { logging company, } \\
\text { international funds }\end{array}$ \\
\hline Transportation means & $\begin{array}{c}\text { Daily opportunities to travel (by bus, car, } \\
\text { motorbikes) }\end{array}$ & 2 & 10 & 10 & 30 & state, private operators \\
\hline $\begin{array}{l}\text { Access to drinkable } \\
\text { water }\end{array}$ & Number of operating water pumps & 0 & 0 & 0 & 1 & state \\
\hline Dispensary & $\begin{array}{c}\text { Availability of medicines and presence of } \\
\text { nursing staff }\end{array}$ & 0 & 0 & 0 & 0 & \\
\hline School & Number of teachers & 0 & 0 & 1 & 3 & self-funding, state \\
\hline Electricity & Number of (working) generators & 0 & 3 & 0 & 2 & self-funding, elites \\
\hline state of personal houses & $\%$ of houses with an iron roof & $32 \%$ & $41 \%$ & $10 \%$ & $12 \%$ & self-funding \\
\hline Communication means & Number of radio stations & 4 & 5 & 4 & 5 & council \\
\hline Shops & Number of (open) shops & 1 & 3 & 2 & 8 & self-funding \\
\hline Trade & Number of markets per week & 0 & 0 & 0 & 0 & \\
\hline Equipment 1 & Number of (working) chainsaws & 0 & 1 & 0 & 8 & self-funding, elites \\
\hline Equipment 2 & Number of (working) motorbikes & 0 & 6 & 1 & 10 & self-funding \\
\hline Equipment 3 & Number of rifles & 1 & 4 & 1 & 10 & self-funding \\
\hline Access to credit & Number of funding organizations & 0 & 1 & 0 & 0 & state \\
\hline Leisure 1 & Existence of a soccer field & No & No & Yes & Yes & \\
\hline Leisure 2 & Number of (working) satellite dishes & 1 & 3 & 0 & 3 & $\begin{array}{l}\text { self-funding, logging } \\
\text { company }\end{array}$ \\
\hline
\end{tabular}

\section{Logging concession and collective or semicollective installations}

National regulations require logging companies to contribute to the improvement of collective infrastructure around their concessions such as schools, dispensaries, or bridges. These investments must answer basic needs of local populations but they can also fund other community initiatives such as semicollective installations that promote development at the village scale. Several assets of physical capital were selected on the basis of the regulatory prescriptions and of similar studies in Cameroon (Sayer et al. 2007, Endamana et al. 2010). The evolution of these assets in the two villages between 1995 and 2008 is reported in Table 2.

The findings at the village level confirm the macrolevel analysis: the direct contribution of the logging company to village infrastructure is weak. The most significant changes between 1995 and 2008, i.e., in transport, numbers of chainsaws and generators, and intra-village trade, are attributable primarily to private and individual investment, which is disconnected from forest management.

\section{Logging concession and local uses of forest resources and space}

Shifting cultivation in the concession area

Timber harvesting prompted the logging company to open a forest track in 1994 from east to west across the concession to access the timber resource, to bring logs to sawmill, and then to forward sawing to Douala for export. This is a private road controlled at each end by a barrier. The western part of this track, i.e. the first $18 \mathrm{~km}$ starting from Djémiong, is located in the village terroirs of three villages, including Djémiong and Gouté. Of these $18 \mathrm{~km}$, only the first two $\mathrm{km}$ are located outside the concession.

Three satellite pictures taken in 1984, 1999, and 2007 were used to assess the extension of agricultural areas along this track. In 1984, the agricultural area covered 55 ha and was located near Djémiong and out of the concession. In 1999, the passing of numerous logging trucks pushed many people to open fields by the roadside to sell their commodities; the swidden agriculture area extended to $88 \mathrm{ha}$, and the extension occurred mainly in the concession. Only five families, however, decided to relocate permanently next to their fields. In 2007, migration increased as 24 households settled within the concession in five hamlets. In addition to these settlements, many villagers asserted their customary rights to create fields along this track while continuing to live in their home villages. Their primary motivation was access to commercial opportunities. The farmland and fallow surface amounted to 272 ha.

This situation is illegal according to the FMP but it is legitimate in the eyes of farmers who exercise their customary rights within "their forests." It illustrates the interactions between logging companies and local populations in the process of 
deforestation in Central Africa; new roads for timber harvesting are then used by people to develop agriculture and access to trade opportunities that are rare in these remote regions. The result is paradoxical: the concession management and the creation or maintenance of tracks encourages people to settle within the concession, which leads to forest degradation due to the extension of shifting cultivation areas. On the other hand, the development of agriculture is a source of improved livelihoods for rural populations, which is also one of the objectives of sustainable forest management.

\section{Intensity of hunting}

The two villages saw most of their hunting territories placed in the concession in 2002. Although hunting is not prohibited, except in the logging area itself, it is a practice regulated according to the FMP. The most logical assumption is the overall reduction in hunting activity in 2008 compared with 1995. Table 3 summarizes all game caught for one year by the sampled households. It shows that the overall number of animals captured in 2008 is higher than in 1995. Except for carnivorous and reptile species, the change in game catches is statistically significant.

Table 3. Number of captured animals in the two villages in a year.

\begin{tabular}{lcccccc}
\hline \hline Family & 1995 & $\%$ & 2008 & $\%$ & $\chi^{2}$ & p-value \\
\hline Duiker & 755 & $36 \%$ & 477 & $17 \%$ & 58.30 & 0.000 \\
Carnivorous & 90 & $4 \%$ & 76 & $3 \%$ & 1.01 & $0.314^{\mathrm{ns}}$ \\
Bird & 134 & $6 \%$ & 74 & $3 \%$ & 17.30 & 0.000 \\
Primate & 153 & $7 \%$ & 393 & $14 \%$ & 107.60 & 0.000 \\
Reptile & 85 & $4 \%$ & 83 & $3 \%$ & 0.02 & $0.877^{\mathrm{ns}}$ \\
Rodent & 914 & $43 \%$ & 1660 & $60 \%$ & 217.20 & 0.000 \\
Wild hog & 10 & $0 \%$ & 2 & $0 \%$ & 5.33 & 0.021 \\
Total & 2141 & & 2764 & & & \\
\hline
\end{tabular}

Six main factors influence hunting level in tropical forests (Nasi et al. 2008): (1) change of natural habitat, which did not occur in the area because timber has remained selectively harvested by the same logging company with the same techniques; (2) higher human population density, which remains moderate in the case study; (3) cultural change and (4) institutional transformation, both of which have not been observed in the studied area; (5) new hunting techniques, proved by the growing number of shotguns in the two villages (Table 2); and (6) economic development with a better level of transportation infrastructure (Mertens et al. 2001) that is manifest in the studied area through an increase in the number of motorbikes (Table 2) and the paving of the road to Yaoundé.

In the surveyed area, easier access to markets combined with the extension of shotgun hunting would allow local populations to provide the urban demand with an increased quantity of large game such as duikers, carnivorous species, and wild hogs. On the other hand, this quantity has declined. The depletion of duikers is found elsewhere in Central Africa and often denotes an overexploitation of these species (Laurance et al. 2006, van Vliet and Nasi 2007). In Gouté and Djémiong, rodents and small primates, which are hunted mainly in the forest-agriculture mosaic, constitute the major preys of hunters. The evolution of hunting in the studied area illustrates a current trend in Central Africa: large game species with low intrinsic rates of population increase and long generation time are the first to disappear, leaving behind only the most resilient and small species with high intrinsic rates of population increase and shorter generation time (Nasi et al. 2008).

The change in the number of hunting trips between the two periods reveals the same variation of animal population (Table 4); hunting is a declining activity, especially when it is practiced inside the logging concession. Because the same decline is also observed outside the logging concession, the decreasing number of hunting visits in the concession is not primarily influenced by the ban of commercial hunting established in the FMP. Villagers generally fall back on garden hunting because the chance of trapping or shooting a large mammal is low, even in forest ecosystems remote from villages. The improvement of the road infrastructure, thanks partly to the logging company, has also not modified hunting practices that still rely mainly on rodent, duiker, and primate species. The overharvesting trend of bushmeat, characterized by the growing fraction of rodents in the total number of captured game at the expense of large game animals, has not been reduced by the formal management of the forest concession.

Table 4. Location of hunting trips in the two villages in a year.

\begin{tabular}{lccrc}
\hline \hline & 1995 & 2008 & $\chi^{2}$ & p-value \\
\hline$\quad$ Inside concession & & & & \\
Gouté & 514 & 209 & 128.7 & 0.000 \\
Djémiong & 418 & 189 & 86.4 & 0.000 \\
$\quad$ Total & 922 & 398 & & \\
$\quad$ Outside concession & & & & \\
Gouté & 327 & 462 & 23.1 & 0.000 \\
Djémiong & 1138 & 841 & 44.6 & 0.000 \\
$\quad 1465$ & 1303 & & \\
$\quad$ Total & 14 & & &
\end{tabular}

\section{Logging concessions and local income}

A presumed direct benefit of logging in Central Africa is the provision of employment to local population. However, it is common that most qualified jobs are taken by external workers and only a few are offered to resident manpower (Brown and Ekoko 2001). The case study is a good illustration of this phenomenon: in 1995, the logging company employed two people from Gouté and Djémiong while, in 2008, there were only five jobs offered to the same villagers out of a working 
Table 5. Gross annual average income per household in the two villages.

\begin{tabular}{|c|c|c|c|c|c|c|c|c|c|c|}
\hline \multirow[b]{3}{*}{ Type of revenue } & \multicolumn{4}{|c|}{ Gouté } & \multirow[b]{3}{*}{ p-value } & \multicolumn{4}{|c|}{ Djémiong } & \multirow[b]{3}{*}{ p-value } \\
\hline & \multicolumn{2}{|c|}{1995} & \multicolumn{2}{|c|}{2008} & & \multicolumn{2}{|c|}{1995} & \multicolumn{2}{|c|}{2008} & \\
\hline & $€$ & $\%$ & $€$ & $\%$ & & $€$ & $\%$ & $€$ & $\%$ & \\
\hline Farm incomes & 180.01 & $52 \%$ & 309.79 & $51 \%$ & 0.065 & 50.94 & $23 \%$ & 183.67 & $26 \%$ & 0.000 \\
\hline Bushmeat, timber, NTFP, fish & 23.65 & $7 \%$ & 105.95 & $17 \%$ & 0.009 & 36.36 & $15 \%$ & 167.96 & $25 \%$ & 0.000 \\
\hline Small business & 46.75 & $14 \%$ & 65.06 & $11 \%$ & 0.000 & 83.18 & $35 \%$ & 126.14 & $19 \%$ & $0.765^{\mathrm{ns}}$ \\
\hline Cash flows & 29.71 & $9 \%$ & 16.71 & $3 \%$ & $0.333^{\mathrm{ns}}$ & 15.11 & $6 \%$ & 53.66 & $8 \%$ & 0.000 \\
\hline $\begin{array}{l}\text { Salaried (informal and } \\
\text { formal) jobs }\end{array}$ & 56.53 & $16 \%$ & 87.64 & $15 \%$ & $0.056^{\mathrm{ns}}$ & 39.89 & $17 \%$ & 144.52 & $21 \%$ & 0.000 \\
\hline $\begin{array}{l}\text { Others (transportation, } \\
\text { sundry) }\end{array}$ & 7.23 & $2 \%$ & 20.50 & $3 \%$ & $0.526^{\mathrm{ns}}$ & 10.13 & $4 \%$ & 4.14 & $0 \%$ & 0.000 \\
\hline Total & 343.89 & & 605.65 & & & 235.61 & & 680.09 & & \\
\hline
\end{tabular}

population of 250 people. This source of revenue related to forest management is far below agriculture revenues, as shown in Table 5, which presents the average annual income in 1995 and in 2008 for the households sampled in the two villages. It is calculated in Euros (1995), using an exchange rate of 656 Central African Francs for 1 Euro and a total inflation rate of consumer prices of $42.8 \%$ for the $1995-2008$ period.

The major sources of revenue have significantly increased in 13 years, according to the Mann-Whitney test with a significant level of $95 \%$. Agriculture remains the major source of income, like in the other rural regions of Cameroon (Folefack 2010). It is accompanied by a strong dependence on natural resources such as fishing at Gouté whereas informal exploitation of timber has soared at Djémiong. This configuration is typical of underdeveloped rural African economies in which direct or indirect on farm activities are predominant (Davis et al. 2009). Three factors support the growth of these rural incomes. The major factor is the growing demand for agricultural and forest products from urban consumers, i.e., for plantain, cassava, and informal timber, as from foreign buyers for cocoa. The second factor comes from an easier access to urban markets with, on one hand, the paving of the Bertoua-Yaoundé road by the state, and on the other hand, the proliferation of "Chinese motorbikes" to reach the neighboring small cities. The maintenance of the local roadway network by the logging company partly contributes to the opening up of this rural region. Last, in addition to the "Chinese motorbikes" effect, the impressive increase in the number of chainsaws played a role in the clearing of larger fields and the growth of agricultural production.

Change in income between 1995 and 2008 shows that the logging concession has not prevented enrichment of these populations although the FMP officially restricts customary access and use rights. However, with the opening of a new road, trade was facilitated and contributed to an extension of agricultural areas. In this case, the logging concession has favored local socioeconomic growth, even if the driving factors of rural development are unrelated to forest management and policy.

\section{CONCLUSION: FOREST MANAGEMENT AND LOCAL PRIVATE INITIATIVES: SOME ROOM FOR IMPROVEMENT}

Analyses conducted at the macro- and microlevels show that direct impacts of sustainable forest concessions on local livelihoods are low. On the one hand, despite the promotion of a participatory approach, local actors' involvement in the forest management process remains superficial; the integration of local knowledge and practices in the FMP is primarily formal without actual implementation on the ground. On the other hand, forest taxes paid by the operator contribute marginally to the improvement of basic infrastructure. Finally, customary rights over forest resources are little constrained by the provisions of the FMP; as a matter of fact, forest management tends to neglect the customary rights as long as they do not affect timber harvesting, which is the primary concern of the logging company.

Still, forest concessions can play a role in opening up rural areas and thus indirectly promote economic dynamics that influence the well-being of local people. The case study shows that improved market access is the result of a combination of factors, i.e., public and private investment, means of conveyance, and attractive prices of agricultural commodities, but that today it is not dominantly influenced by the logging company. However, this logging concession has overcome the threshold effect of relieving forest people from being landlocked. The positive influence of forest concession on local livelihoods can even increase if the logging firm addresses real economic opportunities for rural people. Improving basic infrastructure, as required by regulation, is useful and necessary but does not promote economic development, which rather results from productive activities. Greater complementarity is to be found by logging companies between the legal obligation to participate in building 
community facilities and the support for productive investments that are often private and individual. In the current context of Central Africa, logging companies have three leverages to promote entrepreneurship and economic development:

- Ease of transport to markets has a direct impact on the marketing of products and on farmers' incomes, especially in remote areas. In general, people in connection with urban centers receive more information and training, which extend the development options (Ezzine de Blas et al. 2009). The concession management in Central Africa plays a major role in opening up rural areas, in conjunction with the state's efforts for the extension of its road network.

- The arrival of new production methods, i.e., techniques, crop varieties, and equipment, is rapidly changing local practices. This is generally not the result of forest management, but the logging company can facilitate their dissemination to local communities (Mayers and Vermeulen 2002).

- In the longer term, economic development requires security of forest tenures. Private individual ownership of land or resources is the greatest form of security. Community forestry is another option. The logging company can also recognize within its concession that certain social entities, i.e., community, lineage, family, and individual, have specific rights to certain resources and formally endorse their exercise (Wiersum 2000, Karsenty 2010). Securing local rights of access and use is necessary for the development of private entrepreneurship individually or collectively.

In forest areas, rural development relies on macroeconomic factors that are independent of forest policies (Sunderlin et al. 2000, Wunder 2001, Gbetnkom 2005). However, in the forest zone of Central Africa, most factors of change are influenced by the way concessions are managed; because of the scarcity of state services and the size of the forest concessions, logging companies play a key role in the development of rural areas. Until now their strategy has been to confine themselves to timber management and to comply with legal requirements regarding socioeconomic investments. The increasing pressure of population on forests and the influence of a forest certification process will lead these companies to better take into account the aspirations of local actors. The effort is not necessarily important; it deals primarily with facilitating or supporting existing economic dynamics that have a direct impact on the welfare of rural populations.

Responses to this article can be read online at: http://www.ecologyandsociety.org/voll7/iss1/art7/responses/

\section{Acknowledgments:}

This work was carried out for the project "Popular" with the financial support of the French National Research Agency under the Agriculture and Sustainable Development Programme. The authors thank two anonymous reviewers and Michel Ndoumbe Nkeng for their constructive comments on a first draft of this article.

\section{LITERATURE CITED}

Alden Wily, L. A. 2011. A qui appartient cette terre? Le statut de la propriété foncière coutumière au Cameroun. Rainforest Foundation, London, UK.

Assembe Mvondo, S. 2006. Forestry income management and poverty reduction: empirical findings from Kongo, Cameroon. Development in Practice 16(1):68-73. http://dx.doi.org/10.10 $\underline{\text { 80/09614520500450867 }}$

Bigombe Logo, P. 2004. Le retournement de l'Etat forestier: l'endroit et l'envers des processus de gestion forestière au Cameroun. Presses de l'UCAC, Yaoundé, Cameroon.

Brown, K., and F. Ekoko. 2001. Forest encounters: synergy among agents of forest change in Southern Cameroon. Society and Natural Resources 14(4):269-290. http://dx.doi.org/10.10 $\underline{80 / 08941920151080219}$

Cailliez, F. 1991. L'aménagement des forêts tropicales. Bois et Forêts des Tropiques 227:18-23.

Carrière, S. M. 2002. L'abattage sélectif: une pratique agricole ancestrale au service de la régénération forestière. Bois et Forêts des Tropiques 272(2):45-62.

Cerutti, P. O., L. Tacconi, R. Nasi, and G. Lescuyer. 2011. Legal vs. certified timber: preliminary impacts of forest certification in Cameroon. Forest Policy and Economics 13 (3):184-190. http://dx.doi.org/10.1016/j.forpol.2010.11.005

Chambers, R., and G. R. Conway. 1992. Sustainable rural livelihoods: practical concepts for the 21st Century. Institute for Development Studies, Discussion Paper 296, Brighton, UK.

Collas de Chatelperron, P. 2005. Gestion participative des forêts de production au Cameroun. Bois et Forêts des Tropiques 283:51-63.

Coquery-Vidrovitch, C. 2001. Le Congo au temps des grandes compagnies concessionnaires. Second edition. Mondes d'Outre Mer, Paris, France.

Counsell, S. 2007. For richer, for poorer: logging and livelihoods in the Congo Basin. Pages 107-114 in S. Counsell, C. Long, and S. Wilson, editors. Concessions to poverty - the environmental, social and economic impacts of industrial 
logging concessions in Africa's rainforests. Rainforest Foundation, London, UK.

Davis, B., P. Winters, G. Carletto, K. Covarrubias, E. Quiñones, A. Zezza, K. Stamoulis, C. Azzarri, and S. DiGiuseppe. 2009. A cross-country comparison of rural income generating activities. World Development 38 (1):48-63. http://dx.doi.org/10.1016/j.worlddev.2009.01.003

de Wasseige, C., D. Devers, P. de Marcken, R. Eba'a Atyi, R. Nasi, and P. Mayaux, editors. 2009. Les forêts du Bassin du Congo. Etat des Forêts 2008. European Union Publication Office, Brussels, Belgium.

Delvingt, W., M. Dethier, P. Auzel, and P. Jeanmart. 2001. La chasse villageoise Badjoué, gestion coutumière durable ou pillage de la ressource gibier? Pages 65-92 in W. Delvingt, editor. La forêt des hommes. Terroirs villageois en forêt tropicale africaine. Presses agronomiques de Gembloux, Gembloux, Belgium.

Delvingt, W., and G. Lescuyer. 2007. Certification et gestion forestière: Enjeux et perspectives pour les forêts du bassin du Congo. Pages 62-67 in C. Croizier, and T. Tréfon, editors. Quel avenir pour les forêts de la République Démocratique $d u$ Congo ? Instruments et mécanismes innovants pour une gestion durable des forêts. Coopération Technique Belge, Brussels, Belgium.

Diaw, M. C. 1997. Si, Nda bot and Ayong. Shifting cultivation, land uses and property rights in southern Cameroon. ODI Rural Development Forestry Network, 21e, London, UK.

Diaw, M. C., and P. R. Oyono. 1998. Dynamiques et représentations des espaces forestiers au sud-Cameroun. Arbres, Forêts et Communautés Rurales 15\&16:36-43.

Endamana, D., A. K. Boedhihartono, B. Bokoto, L. Defo, A. Eyebe, C. Ndikumagenge, Z. Nzooh, M. Ruiz-Pérez, and J. Sayer. 2010. A framework for assessing conservation and development in a Congo Basin Forest Landscape. Tropical Conservation Science 3(3):262-81.

Ezzine de Blas, D., M. Ruiz-Pérez, J. A. Sayer, G. Lescuyer, R. Nasi, and A. Karsenty. 2009. External influences on and conditions for community logging management in Cameroon. World Development 37(2):445-456. http://dx.doi.org/10.1016/ j.worlddev.2008.03.011

Folefack, D. P. 2010. Pauvreté et répartition des revenus en zone cacaoyère du Cameroun. Tropicultura 28(1):5-9.

Gbetnkom, D. 2005. Deforestation in Cameroon: immediate causes and consequences. Environment and Development Economics 10(4):557-572. http://dx.doi.org/10.1017/S135577 0X05002330

Hanley, N., J. F. Shogren, and B. White. 1994. Environmental economics in theory and practice. MacMillan, London, UK.
Hoare, A. L. 2007. Integrating local peoples' land use strategies with forest management practices in Central Africa. Rainforest Foundation, London, UK.

Karsenty, A. 1999. Vers la fin de l'Etat forestier? Appropriation des espaces et partage de la rente forestière au Cameroun. Politique Africaine (75):147-61.

Karsenty, A. 2010. La responsabilité sociale et environnementale des entreprises concessionnaires. Pages 35-55 in D. V. Joiris and P. Bigombe Logo, editors. Gestion participative des forêts d'Afrique centrale: un modèle à l'épreuve de la réalité. Quae, Versailles, France.

Karsenty, A., C. Jégou, and B. Singer. 2008. Social policies of forest concessionaires in West and Central Africa. Rights and Resources Initiative, Washington, D.C., USA.

Karsenty, A., L. Mendouga Mébenga, and A. Pénelon. 1997. Spécialisation des espaces ou gestion intégrée des massifs forestiers. Bois et Forêts des Tropiques 251(1):43-54.

Laurance, W. F., B. M. Croes, L. Tchignoumba, S. A. Lahm, A. Alonso, M. E. Lee, P. Campbell, and C. Ondzeano. 2006. Impacts of roads and hunting on Central African rainforest mammals. Conservation Biology 20(4):1251-61. http://dx.doi. org/10.1111/j.1523-1739.2006.00420.x

Le Roy, E., A. Karsenty, and A. Bertrand. 1996. La sécurisation foncière en Afrique. Pour une gestion viable des ressources renouvelables. Karthala, Paris, France.

Lescuyer, G. 2000. Evaluation économique et gestion viable de la forêt tropicale. Réflexion sur un mode de coordination des usages d'une forêt de l'est-Cameroun. Dissertation. Ecole des Hautes Etudes en Sciences Sociales, Paris, France.

Lescuyer, G. 2006. Formes d'action collective pour la gestion locale de la forêt camerounaise: organisations "modernes" ou institutions "traditionnelles"? VertigO 6(3). [online] URL: http://vertigo.revues.org/index8029.html

Lescuyer, G. 2007. Livelihoods and the adaptive application of the law in the forests of Cameroon. Pages 167-190 in L. Tacconi, editor. Illegal logging: law enforcement, livelihoods and the timber trade. Earthscan, London, UK.

Lescuyer, G., and A. Emerit. 2005. Utilisation de l'outil cartographique par les acteurs locaux pour la gestion concertée d'une forêt au sud du Cameroun. Cahiers Agriculture 14 (2):225-232.

Lescuyer, G., H. Ngoumou Mbarga, and P. Bigombe Logo. 2008. Use and misuse of forest income by rural communities in Cameroon. Forests, Trees and Livelihoods 18:291-304.

Long, C. 2007. Land rights and forests: the impact of the concession system. Pages 21-25 in S. Counsell, C. Long, and S. Wilson, editors. Concessions to poverty - the environmental, social and economic impacts of industrial logging concessions in Africa's rainforests. Rainforest Foundation, London, UK. 
Mayers, J., and S. Bass. 2004. Policy that works for forests and people. Real prospects for governance and livelihoods. International Institute for Environment and Development, London, UK.

Mayers, J., and S. Vermeulen. 2002. Company-community forestry partnerships. Frow raw deals to mutual gains? International Institute for Environment and Development, Instruments for Sustainable Private Sector Forestry Series, London, UK.

Mbairamadji, J. 2009. De la décentralisation de la gestion forestière à une gouvernance locale des forêts communautaires et des redevances forestières au Sud-Est Cameroun. VertigO 9(1). http://dx.doi.org/10.4000/vertigo.8614

Mertens, B., E. Forni, and E. F. Lambin. 2001. Prediction of the impact of logging activities on forest cover: a case-study in the East Province of Cameroon. Journal of Environmental Management 62(1):21-36. http://dx.doi.org/10.1006/jema.200 1.0417

Molnar, A., P. Mbile, S. Bandiaki, R. Kozak, K. Canby, and M. France. 2010. Small scale, large impacts. Transforming Central and West African forest industry and trade to improve sustainable development, growth and governance. Rights and Resources Initiative, Washington, D.C., USA.

Morrison, K., P. O. Cerutti, P. R. Oyono, and M. Steil. 2009. Broken promises: forest revenue-sharing in Cameroon. World Resources Institute, Washington, D.C., USA.

Nasi, R., D. Brown, D. Wilkie, E. Bennett, C. Tutin, G. van Tol, and T. Christophersen. 2008. Conservation and use of wildlife-based resources: the bushmeat crisis. Secretariat of the Convention on Biological Diversity, Montreal, Quebec, Canada.

Nasi, R., B. Cassagne, and A. Billand. 2006. Forest management in Central Africa: where are we? International Forestry Review 8(1):14-20. http://dx.doi.org/10.1505/ifor.8.1.14

Nguinguiri, J. C. 1999. Les approches participatives dans la gestion des écosystèmes forestiers d'Afrique centrale: Revue des initiatives existantes. Center for International Forestry Research, Occasional Paper No. 23, Bogor, Indonesia.

Oyono, P. R. 2004. One step forward, two steps back? Paradoxes of natural resources management decentralisation in Cameroon. Journal of Modern African Studies 42 (1):91-111. http://dx.doi.org/10.1017/S0022278X03004488

Oyono, P. R. 2005. Profiling local-level outcomes of environmental decentralizations: the case of Cameroon's forests in the Congo Basin. Journal of Environment and Development 14(2):1-21.
Oyono, P. R., J. C. Ribot, and A. M. Larson. 2006. Green and black gold in rural Cameroon: natural resources for local governance, justice and sustainability. World Resources Institute, Environmental Governance in Africa Working Paper 22, Washington, D.C., USA.

Panayotou, T., and P. Ashton. 1992. Not by timber alone: economics and ecology for sustaining tropical forests. Island Press, Washington, D.C., USA.

Robiglio, V. 2008. Beyond slash and burn: Landscape ecology of shifting cultivation in Southern Cameroon. Dissertation. Bangor University, UK.

Ruiz-Pérez, M., D. Ezzine de Blas, R. Nasi, J. A. Sayer, M. Sassen, C. Angoué, N. Gami, O. Ndoye, G. Ngono, J. C. Nguinguiri, D. Nzala, B. Toirambe, and Y. Yalibanda. 2005. Logging in the Congo Basin: a multi-country characterization of timber companies. Forest Ecology and Management 214 (1-3):221-236. http://dx.doi.org/10.1016/j.foreco.2005.04.020

Sayer, J. A., B. Campbell, L. Petheram, M. Aldrich, M. RuizPérez, D. Endamana, Z. L. Nzooh Dongmo, L. Defo, S. Mariki, N. Doggart, and N. Burgess. 2007. Assessing environment and development outcomes in conservation landscapes. Biodiversity and Conservation 16(9):2677-2694. http://dx.doi. org/10.1007/s10531-006-9079-9

Schlager, E., and E. Ostrom. 1992. Property-rights regimes and natural resources: a conceptual analysis. Land Economics 68(3):249-262. http://dx.doi.org/10.2307/3146375

Scoones, I. 1998. Sustainable rural livelihoods: a framework for analysis. Institute for Development Studies, Working Paper No. 72, Brighton, UK.

Singer, B., and A. Karsenty. 2008. Can concessions be justified? A multidisciplinary perspective from Africa and beyond. Journal of Sustainable Forestry 27(3):224-245. http: //dx.doi.org/10.1080/10549810802256205

Sunderlin, W., O. Ndoye, H. Bikié, N. Laporte, B. Mertens, and J. Pokam. 2000. Economic crisis, small-scale agriculture, and forest cover change in southern Cameroon. Environmental Conservation 27(3):284-290. http://dx.doi.org/10.1017/S0376 $\underline{892900000321}$

Takforyan, A. 2001. Chasse villageoise et gestion locale de la faune sauvage en Afrique. Une étude de cas dans une forêt de l'Est-Cameroun. Dissertation. Ecole des Hautes Etudes en Sciences Sociales, Paris, France.

Topa, G., A. Karsenty, C. Mégevand, and L. Debroux. 2009. Forêts tropicales humides du Cameroun. Une décennie de réformes. World Bank, Washington, D.C., USA. 
Valeix, J. 1999. Quelle démarche d'aménagement retenir en forêt tropicale humide ? Revue Forestière Française 51:333-346.

Vandenhaute, M., and J. L. Doucet. 2006. Etude comparative de vingt plans d'aménagement approuvés au Cameroun. German Technical Cooperation, Yaoundé, Cameroon.

Van Dorp, M. 2007. Economic impacts of industrial logging concessions: what are the benefits? Pages 82-95 in S. Counsell, C. Long, and S. Wilson, editors. Concessions to poverty - the environmental, social and economic impacts of industrial logging concessions in Africa's rainforests. Rainforest Foundation, London, UK.

Van Vliet, N., and R. Nasi. 2007. Mammal distribution in a Central African logging concession area. Biodiversity and Conservation 17(5):1241-1249. http://dx.doi.org/10.1007/s10 531-007-9300-5

Vermeulen, C., and A. Karsenty. 2001. Place et légitimité des terroirs villageois dans la conservation. Pages 217-234 in W. Delvingt, editor. La forêt des hommes. Terroirs villageois en forêt tropicale africaine. Presses agronomiques de Gembloux, Gembloux, Belgium.

Wiersum, F. K. 2000. Incorporating indigenous knowledge in formal forest management: adaptation or paradigm change in tropical forestry? Pages 19-32 in A. Lawrence, editor. Forestry, forest users and research: new ways of learning. European Tropical Forest Research Network, Wageningen, the Netherlands.

Wilson, S. 2007. Economic theory and justification for the industrial forest logging concessions systems. Pages 96-106 in S. Counsell, C. Long, and S. Wilson, editors. Concessions to poverty - the environmental, social and economic impacts of industrial logging concessions in Africa's rainforests. Rainforest Foundation, London, UK.

Wunder, S. 2001. Poverty alleviation and tropical forests what scope for synergies? World Development 29 (11):1817-1833. http://dx.doi.org/10.1016/S0305-750X(01)00070-5 